\title{
喉頭機能の反射性制御: 粘膜の振動刺激が反回神経反射に及ぼす影響
}

\author{
千葉大学医学部耳鼻咽喉科学教室（主任：金子敏郎教授） \\ 千葉大学医学部第一生理学教室（指導：中島祥夫教授） \\ 持 田晃 \\ REFLEX CONTROL ON LARYNGEAL FUNCTIONS \\ — VIBRATION EFFECT OF THE LARYNGEAL MUCOSA \\ ON RECURRENT LARYNGEAL NERVE REFLEXES -
}

AKIRA MOCHIDA, M.D.

Department of Otorhinolaryngology and Physiology, School of Medicine, Chiba University, Chiba

Electromyographic (EMG) responses of the intrinsic laryngeal muscle have been investigated to clarify reflexogenic laryngeal controls from a viewpoint of its functional significance during phonation.

Twenty-five adult cats were anesthetized with intraperitoneal injection of $4 \mathrm{ml} / \mathrm{kg}$ of a mixture of $10 \%$ urethane and $1 \%$ alpha-chloralose. Either the internal branch of the superior laryngeal nerve (ISLN) or the recurrent laryngeal nerve (RLN) was carefully dissected and central end of the dissected nerve was electrically stimulated. EMG of the contra-lateral Thyro-Arytenoid muscle (TA muscle) to the stimulation was recorded using a hooked-wire electrode inserted through the laryngeal mucosa.

EMG of the TA muscle evoked by the stimulation of the ISLN were analized with respect to its latency and discharge pattern either in intact cat or inter-collicular brainstem transsected.

Together with the electrical stimulation of the RLN, vibratory stimuli were given mainly to the subglottic mucosa as conditioning stimuli. The vibratory frequency was changed from $50 \mathrm{~Hz}$ to $400 \mathrm{~Hz}$ stepwisely.

Following results were obtained.

1. EMG response of the contra-lateral TA muscle to the stimulation of the ISLN showed two different kinds of latency, approximately $8-10 \mathrm{msec}$, and $40-60 \mathrm{msec}$.

2. After inter-collicular brainstem transsection, evoked response of the latter disappeared.

This result indicates that the ISLN-RLN reflex loop consisted of more than two routes, different in the number of synaptic junctions.

3. The vibratory stimuli given to the laryngeal mucosa had facilitatory effect on the reflexive EMG response evoked by the stimulation of the RLN.

4. This facilitatory effect of the vibratory stimuli disappeared after topical anesthesia of the laryngeal mucosa.

5. The facilitatory effect on the reflex responses was partially increased depending on the vibratory frequencies applied. 
In conclusion, vibratory stimuli to the laryngeal mucosa reflexively modulate the activity of the intrinsic laryngeal muscles.

Key words : 内㗋頭筋, 誘発筋電図, 振動刺激, ネコ

A $93-0938-60020$

\section{はじめに}

喉頭の基本的機能は，喉頭を強く閉じることで下気 道の保護を目的とする知頭舷扼機能, 犊頭を開いて気 道の一部とする呼吸機能，そして音を生成する発声機 能の 3 つに大別される

これらのうち系統発生学的にみると,最も原始的で, かつ重要な機能は下気道の保護を目的とした喉頭絞扼 機能である。喉頭を有するほとんどの種において，下 気道保護のための声門閉鎖反射が認められる，上㬋頭 神経内枝を始めとする上気道に分布する知覚神経の刺 激により声門閉鎖反射が惹起されることは，諸家によ り報告されている(2) .

一方，系統発生学的には最も新たに獲得された発声 機能については，多くの研究者により得られた種々の 生理学的知見より，精巧な調節機構が存在すると考え られている.これには，聴覚によるフィードバック機 構, 咽頭, 喉頭における触覚によるフィードバック機 構, 内崌頭筋, 助間筋などの呼吸筋における筋紡錘, 嶦頭の軟骨性関節包の知覚受容器を介する固有知賞性 フィードバック機構，さらには中枢神経内部における フィードバック機構が推定されている゙．

これらの精巧なメカニズムにより，発声前の presetされた声帯の位置を始めとする声道の状態が, 動 的な発声という状態の中で反射的に調節, 維持され, 一定のピッチ, 強さでの発声が可能となると考えられ ている.

本研究では実験動物におりるる各種刺激に対する㑨頭 反射を内喉頭筋筋電図を指標として観察し，その反射 に対する喉頭粘膜の振動刺激扔よび反回神経の関与に ついて，主として発声の調節という観点から検討を行 วた.

\section{対象および方法}

実験には体重 1.4-4.0Kgの成猫25頭を用いた。麻 醉は10\%ウレタン，1\%アルファクロラロース $4 \mathrm{ml} /$ $\mathrm{Kg}$ の腹腔内注射にて行った。

前頸部正中に䋛切開を招き, 胸鎖乳突筋を左右に分 割の上，胸骨舌骨筋を切除して喉頭を露出した。第 2
気管輪より $3-4$ 気管軟骨の気管を，その背側を走行 する反回神経を損傷せ奴うに充分注意を払って除去 し，その末梢側に自作のガラス製 L 字型カニューレを 装着し，自然呼吸をさせた。

喉頭は，之の内腔上り筋電図用ワイヤ一電極を挿入 し，また声門下喉頭粘膜に振動刺激を加えることが出 来るように, 腹側正中で縦切開し輪状軟骨の断端に糸 をかけ展開，固定した。

実験中ネコは成茂製脳定位固定装置を用いて背臥位 に固定し, 啹頭㧍よび剥離した神経組織の乾燥を防ぐ ため, 加温した流動パラフィンのプールを前形部の皮 膚を利用して作成した。

大腿静脈にカテーテルを挿入し，実験中の麻酔薬を はじめとする各種の投薬，輸液に用いた。 また，直腸 温をモニターし, 赤外線ランプ, 手術用保温マットに より体温を $37-38^{\circ} \mathrm{C}$ に維持した。

電気刺激として, 上喉頭神経内枝, あるいは反回神 経に双極銀線電極を用い, 持続時間 $0.2 \mathrm{msec} の$ 矩形波 刺激を単発で，あるいはトレインとして加えた。刺激 の基本的な周期は, 実験動物の胸壁にセンサーを装着 し,一呼吸周期に 1 回の刺激を加えた。呼吸相は今回 の実験では特に指定しなかった。これに対して，反復 刺激は呼吸相に無関係に 1- $10 \mathrm{~Hz}$ の間で連続的に刺 激を加えた。なお，トレイン刺激においては，この反 復刺激を反回神経に加えることにより，心停止を起こ す場合が認められたので，最大 $1 \mathrm{~Hz}$ とした。振動刺激 は EXACT 社 Model 126 Function Generator で作成 した正弦波で，サーボコントロール機構を内蔵するバ イブレーターIMV 社 DSS-04P Medical Pulser を駆 動することにより得た。このバイブレーターに先端直 径 0.75mmのガラ久棒を装着し, 主として声門下の喉 頭粘膜见持続性正弦波振動刺激を加えた。

筋電図記録には, 直径 $0.12 \mathrm{~mm}$ のポリウレタンで被 覆された一対の銅線を用いて hooked wire electrode ${ }^{10)}$ 自作し，明状披裂筋に喉頭内腔より粘膜 を賁いて刺入した。

筋電図は生体用アンプ日本光電社 bioelectric amplifier AB-651J にて增幅 (Band pass filter ; $100 \mathrm{~Hz}$ 
$-3 \mathrm{KHz})$ し，オシロスコープに表示すると同時に，

Audiomonitorに接続された.

筋電図, 電気刺激, 振動刺激はさらに, TEAC 社デ ータレコーダーMR-30を用いて磁気テープに保存 し, 日本電気三栄社シグナルプロセッサー7T-17によ り, off-line で潜時の計測，さらに筋電図波形の積分， 加算平均処理, 積分値 (面積值) の算出を行った.

本研究では以下の実験を行った。

1）一側の上唉頭神経内枝を甲状軟骨の直前で切断 し，その中枢端に双極銀線電極を用いて電気刺激を加 え，反対側の甲状披裂筋より誘発筋電図を記録し，そ の潜時, パターンを検討した，また，誘発筋電図の電 気刺激を単発，およびトレインとし，それによる潜時， パターンの変化について検討した。

2）一側の反回神経は切断のうえ，その中枢端に電 気刺激を加え，反対側の甲状披裂筋より誘発筋電図を 記録し，その潜時，パターン，また各種刺激に対する 反応の変化を検討した.

さらに, この反応に対して, 電気刺激側の主に声門 下の堠頭粘膜に加えた持続性の振動刺激が与える影響 を検討した。喉頭粘膜に振動刺激を条件刺激として加 えた場合には，反回神経は切断せず，電気刺激を加え た. また, 振動刺激の振動周波数による影響, 振動刺 激を加えた粘膜の場所による影響の違いについても検 討した.

3）この誘発筋電図の起源を探る目的で脳幹切断実 験を行った. 脳幹切断は後頭蓋窩より小脳テントに沿 って外科的に切断する方法を用いた。切断後 2 時間以 上の経過の後再び誘発筋電図反応を観察した. 実験終 了後, 脳幹切断を確認した.

\section{成 績}

\section{I . 上喉頭神経内枝刺激}

一側の上喉頭神経内枝を唉頭に入る直前で切断し, その中枢端に電気刺激を加えると, 反対側の甲状披裂 筋より誘発筋電図反応が得られた（図 1 )。

単発刺激による甲状披裂筋の誘発筋電図波形を 0 加 ら $100 \mathrm{msec}$ まで観察すると，その刺激の強さにより異 なる波形が得られた，図 2 上段にみられるように刺激 の比較的弱い範囲では, 実験動物の麻酔深度をはじめ とする種々の条件にもよるが, 潜時 8-10 $\mathrm{msec}$ に立ち 上がりを持つ波形のみが認められた。

さらに, 刺激の強さを高めると潜時 8-10msec に立 ち上がりを持つ波形に加えて, 潜時 40-60 $\mathrm{msec} に$ 立

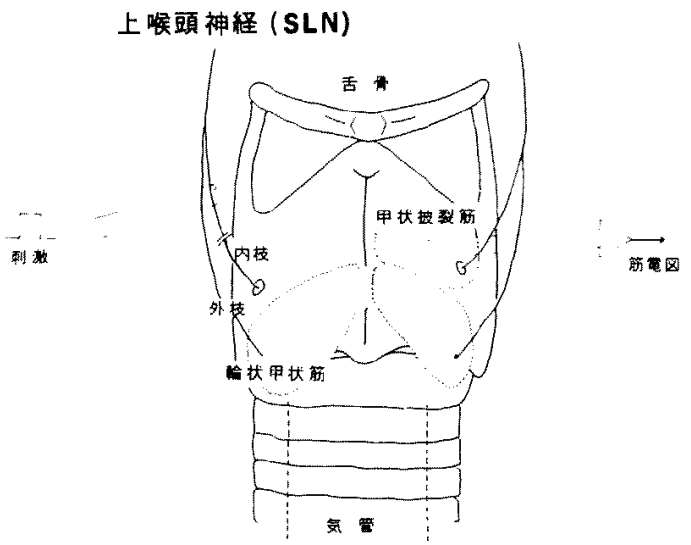

反回神程 (RLN)

图 1 実験の模式図

上喉頭神経内枝を電気刺激し，对側甲状披 裂筋より筋電図を記録する。
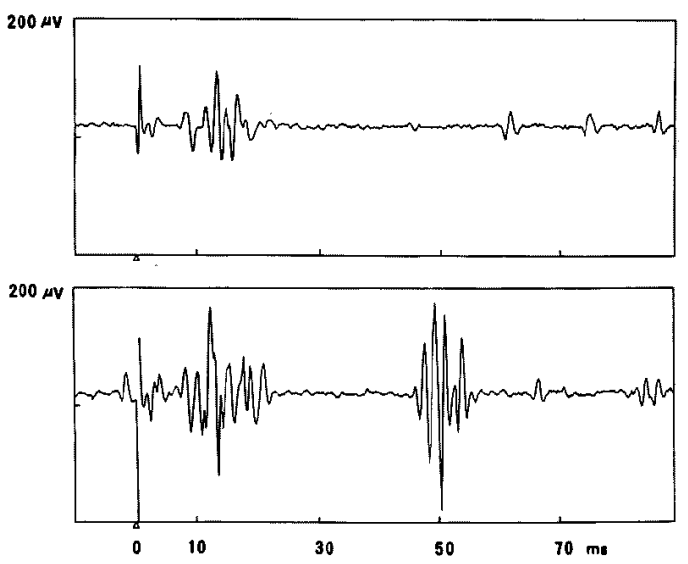

図 2 上喉頭神経内枝の単発電気刺激に上る対側 甲状披裂筋における誘発筋電図反応

上段：立ち上がり潜時 $8-10 \mathrm{msec} の 反$ 応波 形 (early response). 弱刺激のとき

下段：上段の反応波形に加え，潜時40一60 msec $の 反$ 応波形 (late response) の 出現を見る.強刺激の上き

ち上がりを持つ反応波形が出現し(図 2 下段)，ここで 便宜上, 潜時の短い反応波形を early response, 潜時 の長い反応波形を late response と呼ぶ.

単発刺激の場合, early response は刺激が闘値に達 するとほとんど全例で認められる反応波形であり，そ の潜時は 8-10msec の間で非常に安定した值を示し た.

これに対して, late response の潜時は 40-60 msec の間をとることが多く，その標準偏差は early 
表 1 上喉頭神経内枝刺激による对側甲状披裂筋 における誘発筋電図反応の潜時

\begin{tabular}{lcc}
\hline 刺激様式 & $\begin{array}{c}\text { 潜 } \\
\text { Early Response } \\
(\mathrm{msec})\end{array}$ & $\begin{array}{c}\text { 時 } \\
\text { Late Response } \\
(\mathrm{msec})\end{array}$ \\
\hline 単 発 刺 激 & & \\
Early Response only & $10.4 \pm 1.1$ & \\
Early \& Late Response & $9.2 \pm 0.3$ & $40.1 \pm 3.9$ \\
\hline トレイン刺激 & & \\
2 Pulses/10 msec & & \\
Early Response only & $9.7 \pm 0.4$ & \\
$\quad$ Early \& Late Response & $8.7 \pm 0.6$ & $41.6 \pm 5.4$ \\
4 Pulses/10 msec & & \\
$\quad$ Early Response only & $8.5 \pm 0.2$ & \\
$\quad$ Early \& Late Response & $8.2 \pm 0.8$ & $41.7 \pm 5.3$ \\
\hline
\end{tabular}

responseに比較して大きく，また必ずしも全試行で認 められる反応ではなかった。

トレイン刺激による誘発筋電図においても，単発刺 激の場合と同様に潜時の異なる 2 種の反応波形が認め られた。この場合の各反応の潜時は単発刺激の場合の early response, late response の潜時とほほ同一の值 であった (表 1).

大腿静脈に留置したカテーテルよりウレタン，アル ファクロラロースを追加することにより麻酔深度を深 くすると, early response はほとんど変化を示さなか ったが, late response 汸次第に出現しにくくなった。

また，上堠頭神経内枝に対する電気刺激を反復する と early responseにはほとんど変化は認められなか ったが, late response は減衰を示し，次第に出現しな い状態が続くようになった。

early response, late response に認められた以上の 相違点より，上喉頭神経内枝より迷走神経を経由して 孤束核に至る求心路と，疑核を中心に存在する内喉頭 筋の motoneuron pool からの遠心路との間, すなうち 上㖠頭神経一反回神経反射経路には長短の 2 種類の経 路が存在し, early response, late responseはそれら 複数の経路に由来する反応波形である可能性を認めた ので, 脳幹切断実験を行った.

脳幹切断前に準備実験として, 予め early response, late response が出現することを確認した後（図 3 上 段), 後頭蓋窝を開頭し小脳テントに沿って外科的に脳 幹を切断した。この方法ではほほ上, 下丘の間の高さ て脳幹を切断することになる，切断後， 2 時間以上の
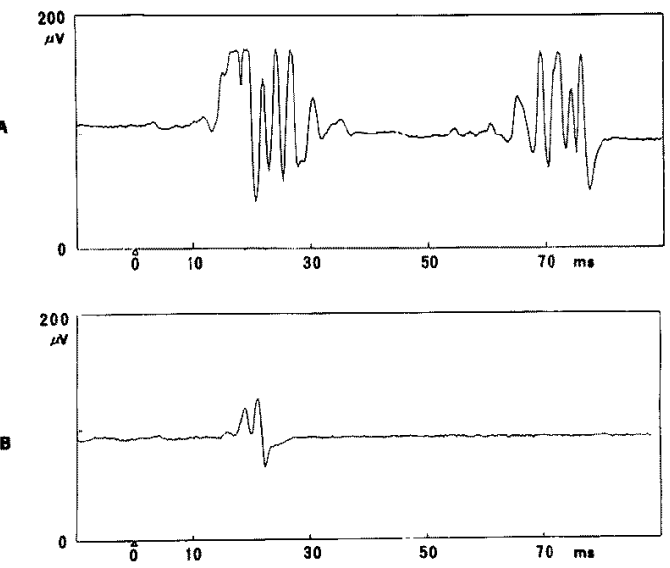

図3 上，下丘間での細幹切断ネコの上侯頭神経 内枝刺激に上る対倒甲状披裂筋に拸ける誘 発筋電図反応 $\mathrm{A}$ : 切断前. B：切断後.

経過の後，実験を再開した。

脳幹切断ネコでは，上喉頭神経内枝刺激に対する誘 発筋電図には early responseに相当する潜時の反応 波形は認められたが， late response に相当する反応 は，単発刺激で刺激の強度を強めても認められず，さ らにトレイン刺激の形で刺激の強度を強めても, late response は出現しなかった。(図 3 下段).

脳幹切断によるショックの影響を除くため,さらに 経時的に実験を行ったが late response は出現しなか った.

II 、 反回神経刺激

一側の反回神経を切断のうえ，その中枢端に電気刺 

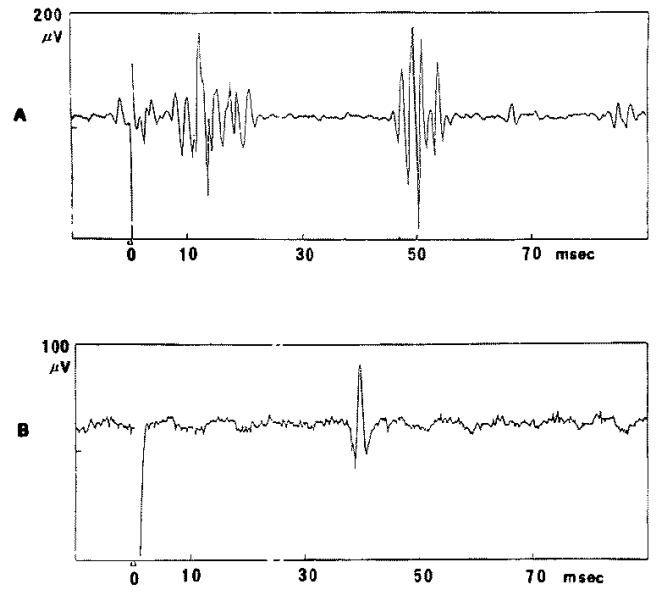

图 4 甲状披裂筋における誘発筋電図反応

$\mathrm{A}$ ：上喉頭神経内枝刺激による

$\mathrm{B}$ ：反回神経刺激による

表 2 反回神経刺激による対側甲状披裂筋 に扔ける誘発筋電図反応の潜時

\begin{tabular}{cc}
\hline 刺 激 樣 式 & 潜時 $(\mathrm{msec})$ \\
\hline 単 発 刺 激 & $36.2 \pm 0.9$ \\
\hline トレイン刺激 & \\
2 Pulses $/ 10 \mathrm{mses}$ & $32.3 \pm 3.1$ \\
4 Pulses $/ 10 \mathrm{mses}$ & $35.2 \pm 3.3$ \\
\hline
\end{tabular}

激を加えると，反対側の甲状披裂筋より誘発筋電図が 得られた。上喉頭神経内枝と同様に, 単発およびトレ イン刺激を行うと潜時 $35-45 \mathrm{msec} に$ 立ち上がりをも つ反応波形のみが認められた(図 4 下段)。その潜時は 単発刺激, トレイン刺激の間でほとんど違いはなかっ た(表 2 ).

この反応波形は上喉頭神経内枝を刺激した場合の

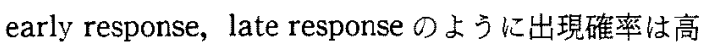
くなく，全試行で認められる反応ではなかった。また， 刺激を反復すると速やかにかつ著しい減衰を示し(図 $5)$ ，上喉頭神経内枝刺激の誘発反応と際立つた差異を 示した.

III. 喉頭粘膜振動刺激と反回神経刺激

声門下の搌頭粘膜に持続性振動刺激を加えて, 喉頭 粘膜の知賞受容器を介する入力が反回神経刺激の誘発 反応に对して，どのような影響を与えるか，を検討す る目的で次の実験を行った。

振動剌激は, バイブレーターを用いてネコの鳴き声
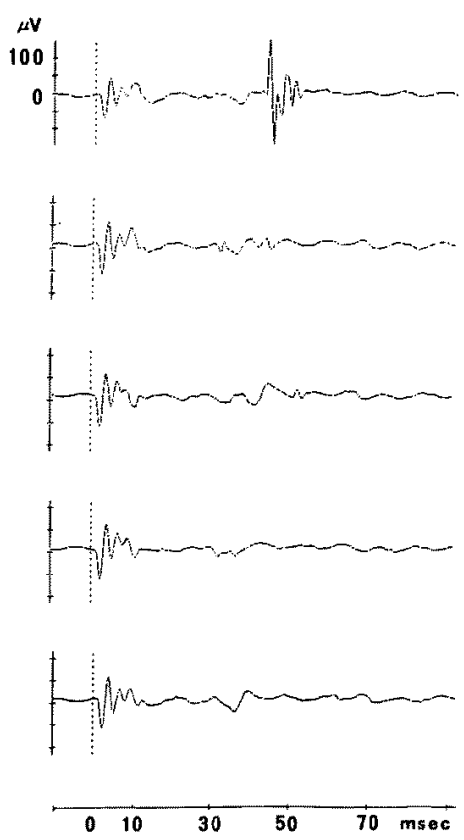

园 5 反回神経刺激に上る対側甲状披裂筋におけ る誘発筋電図反応の減衰

最上段より連続して与えた 5 回のトレイ ン刺激に対する応答を示す。最上段の 1 回 目の刺激に対しては明瞭な反応が認められ るが， 2 回目以降の刺激に対しては反応は 認められない。刺激直後の波はトレイン刺 激によるアーティファクト。

の基本周波数が $200-400 \mathrm{~Hz}$ であること ${ }^{11)}$ ，使用した バイブレーターの周波数特性を考慮して $50 \mathrm{~Hz}$ より $400 \mathrm{~Hz}$ まで変化させた，振動の振幅は周波数に関倸な く $40 \mu \mathrm{m}$ と一定にした.

喉頭粘膜に振動刺激を条件刺激として加えた場合に は，反回神経は切断せず，電気刺激を加えた。この場 合, あらかじめ準備実験として電気刺激のみを加え, 反応潜時が反回神経切断の場合と相違の認められない ことを確認した上で，実験を施行した。また，実験結 果の解析にあたっては，反応波形の加算平均処理に際 して時間ゲートをかけて，他の反応を除外するように した.

記録された筋電図は, off-line で時定数 $10 \mathrm{msec}$ の積 分回路を通したのち, シグナルプロセッサーを用いて 10回の加算平均処理し，加算波形の積分值（面積）を 求めた．振動刺激を与えなかった時の積分值を分母と し, 振動刺激のこの誘発筋電図反応に対する効果を比 として算出した。この計算処理にあたり，実験動物の 


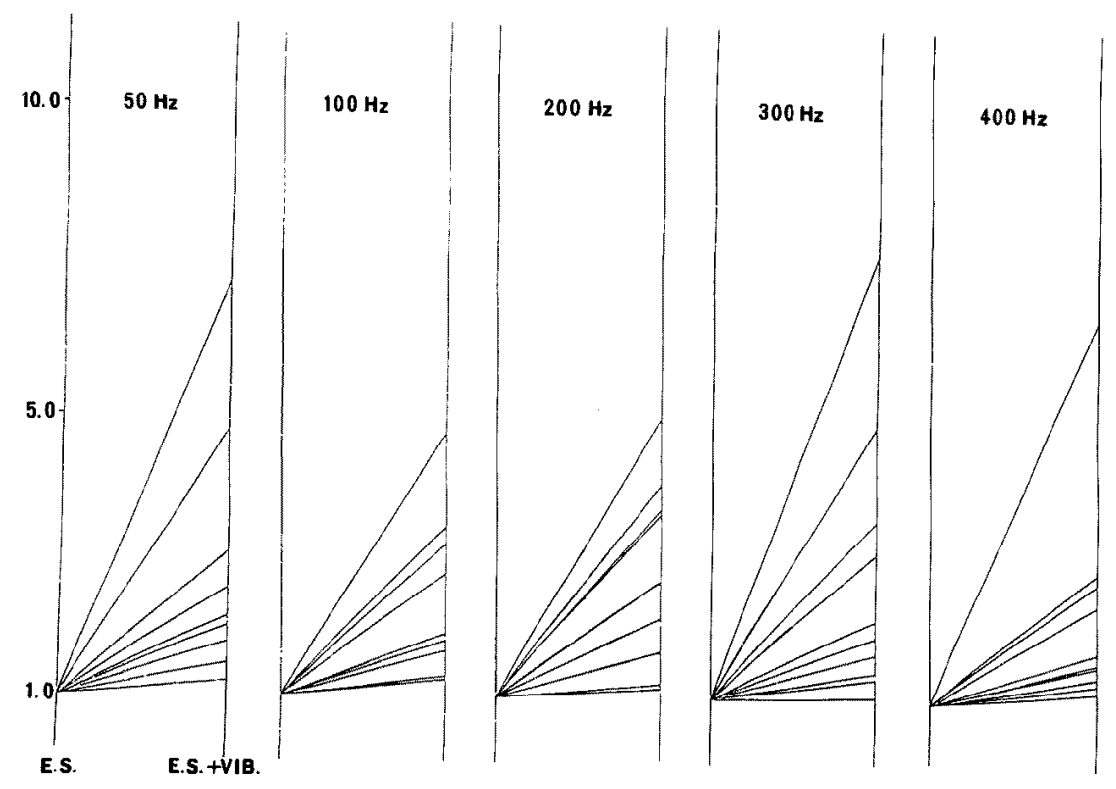

図 6 振動周波数別の反回神経剌激による対側甲状披裂筇に扔ける誘発筋電図 反応の促通効果

左列：電気刺激のみの場合の誘発筋電図の積分值を 1 として,(コントロ 一ル)

右列：振動刺激を加えた場合の誘発筋電図の積分值をコントロールとの 比として表した。

E.S. : 電気刺激

E.S.+VIB. : 電気刺激＋振動刺激. 振動周波数は各列上段に示した。

個体差, 麻酔深度などの実験条件の差異を考慮に入れ， 皘分值の比は同一実験個体ごとに算出した。

その結果, $50 \mathrm{~Hz}$ から $400 \mathrm{~Hz}$ まで振動周波数に関係 なく振動刺激によって積分值の比は 1 以上となった (図6).

以上より，喉頭粘膜に加えられた振動刺激により反 回神経刺激による甲状披裂筋誘発筋電図反応は促通さ れることが明らかとなった。

㬋頭粘膜に表面麻酔を行い，同様の実験を行ったと ころ、この促通効果は抑制された。

振動刺激を加える部位を, 声門下 subglottis と披裂 部隆起 Arytenoid Eminence に大きく2つに分けて振 動刺激の効果を検討した，その結果, 種々の反応が泥 在し，一概に指摘することのできる傾向は認められな かったが，いずれの場合も振動刺激は反回神経刺激誘 発反応に対して促進効果を示した.

さらに，声門下，披裂部隆起のいずれを刺激した場 合においても, 加えた振動刺激の振動周波数とは無関 係に促進効果を示したものと, 振動周波数とある程度
対応した促通効果を示したものの雨方が認められた (図 7).

\section{考察}

喉頭の機能の中で最も原始的で, かつ生理学的に重 要なものに, 下気道への異物の侵入を防ぐ啹頭絞扼機 能，下気道の保護機能がある. 声帯より口側の㸶頭， 知頭粘膜を機械的に刺激したり，実験的に上噍頭神経 内枝を電気刺激することにより観察される反射性の声 門閉鎖がこれにあたり，声門閉鎖反射と呼ばれる゙2 声門閉鎖反射は，一般的には甲状披裂筋を中心とし た声門閉鎖筋群の反射性収縮と声門開大筋である後輸 状披裂筋の反射性抑制によって生じると考えられてい る

村上によれば，ネコの上䐅頭神経内枝に単発刺激を 加え声門閉鎖反射を惹起すると, 内知頭笳群のうち甲 状披裂筋, 側輪状披裂筋, 披裂間筋, 輪状甲状筋に著 明な反射波が生じる，さらに後輪状披裂筋にも適度の 反射性収縮が生じ，このため緊張の強い声門閉鎖とな 
声門下に振動刺激を加えた場合

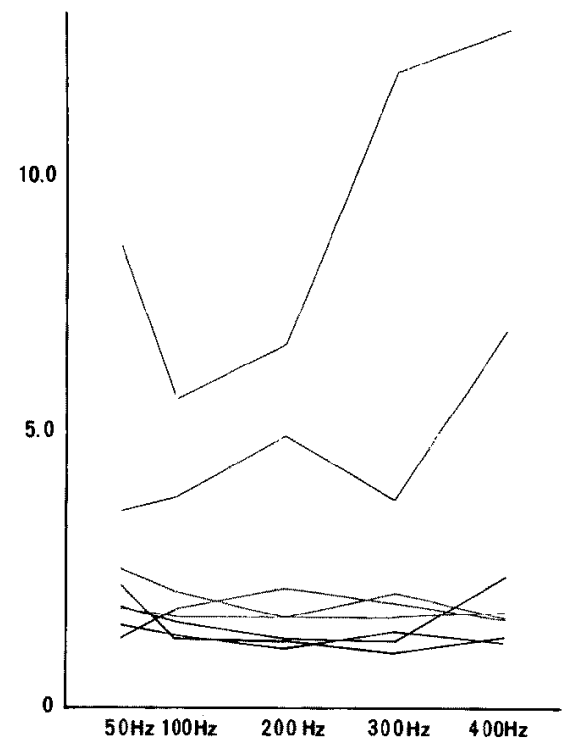

披裂部隆起に振缜刺激を加えた坦合

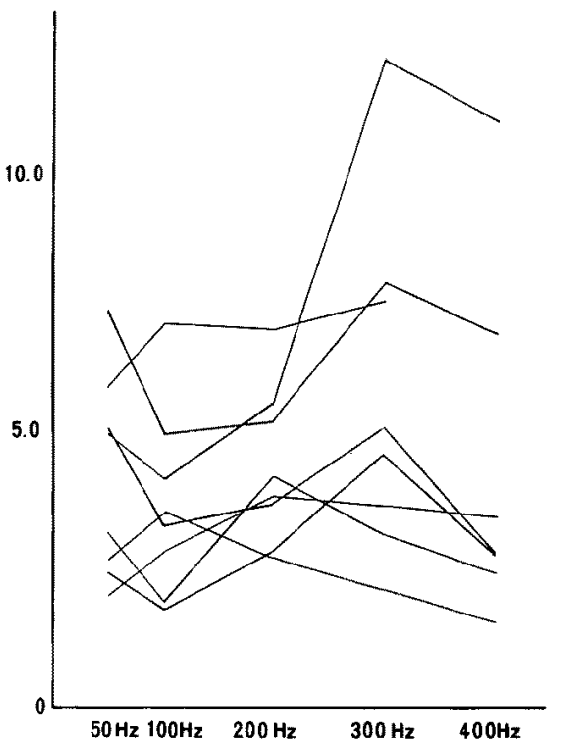

図 7 振動刺激の周波数 (横軸) と反回神経刺激による対側甲状披裂筋におけ る誘発筋電図反応に対する促通効果 (綐軸) との関係.

左側はsubglottisに，右側はArytenoid Eminenceに振動刺激を加えた 場合が示されている。

るという。さらに，強い刺激または弱い刺激でも連続 的に与えられた場合には，反射波の他に大きな電位が 持続的に誘発され，剌激を止めた後にもこれが持続す ることを報告し, spastic after-discharge と名付けて いる(4).

村上の報告によれば，上喉頭神経内枝の単発刺激に よる反射波の筋電図的检討では，甲状披裂筋には最も 顕著な反射波が認められ，その潜時は 7-8msec, 持続

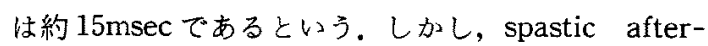
dischargeについては潜時, 持続についての報告はな (1) $^{(4)-19)}$.

また，山際はネコの上喉頭神経内枝を電気刺激し， 反回神経加らの誘発神経電位を観察して，この反射応 答が反復刺激によっても容易に減衰しないことを認め た、一般に反射経路に含まれるシナプスの数が多いほ ど, 反復刺激に対する応答に減衰が生じやすいと言わ れていることより，上喉頭神経一反回神経反射経路に 含まれるシナプスの数がきわめて少ないと推測してい る.さらに, 上昵頭神経内枝刺激による反回神経の反 射応答が 2 峰性を示し, 先発の峰に比べ後発の峯が反 復刺激に対して減衰しやすいことより，上喉頭神経一 反回神経反射経路には少なくとも2 20経路か存在す
ることを示唆している。その最短経路として孤束核か ら直接同側の疑核にいたる経路の存在を想定してい $乃^{20121 !}$.

今回の実験では甲状披裂筋より得られた上喉頭神経 内枝刺激に対する反射応答の潜時は，麻酔条件などが 異なるため一概に結論をだすことには慎重でなくては ならないが，村上の報告とほほ一致していた。

spastic after-discharge については潜時, 持続に関 する定がなされていないため，直接比較することは 出来なかった。

今回得られた潜時の異なる2種類の筋電図反応波形 は, 山際により報告された上喉頭神経刺激の際の反回 神経神経電位の 2 峰性の反射応答に相当するものと考 えられた。

本研究では，この筋電図における2峰性の反射応答 を early response, late response と便宜上呼称し, そ の特性を検討した。その結果, early response, late responseの間には潜時, 持続以外にも間值，麻酔に対 する反応，反復刺激に対する応答に明瞭な相違が存在 し, 種々の生理学的知見より,これらの相違点は主に 反射経路に含まれるシナプスの数の違いによるものと 推察された。 
A. Carはヒツジの上堠頭神経の afferent fiber が, 孤束核に投射するとともに，上行線維により ponsの primary relay nucleus, Thalamus $\sigma$ VPM 核を介し て大脳皮質に投射していることを電気生理学的手法を 用いて，その潜時を含めて報告している22).

これらの知見をふまえて，この early response, late response が 2 つ以上の異なる経路に由来する反射波 形であることを確かめるため，上，下丘間での脳幹切 断実験を行った. 本研究で得られた脳幹切断に上る late response $の$ 消失という結果は, 上喉頭神経一反回 神経反射経験は孤束核，疑核を経由するものと，少な くとも1つは中脳以上を経由する複数の経路から成り 立っていることを示すものと考えられた。

犊頭からの主たる感覚神経の経路は上喉頭神経内枝 である.声門より口側の粘膜扔よび媣部構造からの求 心性線維はほとんど上喉頭神経を経由する。ささらに, 田中, Yoshida らの五唉頭における感賞神経線維の 走行を Horse Radish Peroxidase (HRP) を用いて検 討した報告によれば，ネコでは上㘈頭神経内枝は声門 上のみならず両側の声門下の知覚をも感受していると (ว32) 26).

一方反回神経にも求心性線維が含まれていること が, Hirose $の$ slowly-adapting stretch receptor 加 の求心性発射の反回神経からの記録 ${ }^{27)}$, Bianconi \& Molinari に上る喉頭内筋紡鍾由来上考えられる求心 性発射の記録 ${ }^{28)}$, 三浦による声門下喉頭粘膜に存在す る知賞受容器の周波数特性の解析 ${ }^{2930)}$, Davis \& Nail

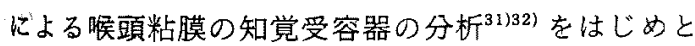
する多くの報告により明らかになっている。

しかしながら，反回神経に含まれる求心性線維の刺 激による誘発反射応答についての報告は少なく，わず 加に Suzuki \& Kirchnerによる報告 ${ }^{33)}$ を認めるに過 ぎないが，それによると，反回神経一反回神経経路の 神経電位における潜時は同側で $25 \mathrm{msec}$, 反対側で $40 \mathrm{msec}$ という。

本研究では, 反回神経一反回神経経路については反 対側の場合のみ検討して扔り，その潜時は約 35一 45msec と Suzuki \& Kirchner の報告とほほ一致した 值を示した。

さらに本研究では，この反回神経刺激による甲状披 裂筋誘発反応は反復刺激に対して著しい減衰を速やか に示すことが明らかとなった。この反応様式は同じ迷 走神経の枝である上喉頭神経内枝を刺激した場合と際 立った相違を示した。
この減衰しやすい反回神経刺激による誘発反射応答 を検討するために，条件刺激として主として声門下抽 よび披裂部隆起の大きく分けて2つの部分の喉頭粘膜 に持続性正弦波振動刺激を加えた。 その結果, 喉頭粘 膜に加えた振動刺激は, 反回神経刺激の誘発反応に対 して促通効果を持つことが明らかとなった。

この促通効果は喉頭粘膜に局所麻酔薬を作用させる と消失することが認められたことから，喉頭粘膜およ びその周囲の知覚受容器が, この促通効果に関与して いることが強く示唆された。

喉頭粘膜に加兄られた振動刺激による甲状披裂筋に おける反射応答に対する促進効果を振動周波数と振動 刺激を加えた部位について検討した。

振動刺激周波数別の諉発筋電図の積分值の比法いず れの場合も1以上となり，今回の実験ではその平均值 としては $300-400 \mathrm{~Hz}$ に扔いてピークをとると考えら れた。

振動刺激を加える部位別に振動刺激の効果を検討寸 るため, 発声時に粘膜波動を生じ，最も振動する部分 である声門下と，披裂部隆起を振動刺激部位として選 択した。披裂部隆起は三浦による喉頭粘膜の知賞受容 器の周波数特性による分類において $500 \mathrm{~Hz}$ まで対応 しうる $\mathrm{F}_{\mathrm{H}}$ グループの知覚受容器が多く分布する部分 である291301.

その結果，いずれの部分に振動刺激を加えても誘発 反忘は促進され，加振動刺激周波数に無関係の促通 効果を得る場合と，振動周波数にある程度，依存した 促通効果を得る場合が認められた。特に，披裂部隆起 を刺激した場合に振動周波数に応じた促通効果を得る ことが多かった。

ここで本研究で明らかとなった喉頭における反射応 答の生理学的意義について考察を加えたい.

上㬋頭神経内枝を電気刺激した際に誘発される甲状 披裂筋をはじめとする声門閉鎖筋群における反射波 は，薙頭の最も基本的な機能である下気道の保護を目 的とした声門閉鎲反射と呼ばれる反射によるものであ 子.

本研究による early response は従来の研究者の報 告とよく一致した潜時を示した。さらに，脳幹の切断 により late response の消失を認めたことより, 上喉頭 神経一反回神経反射経路にはシナプスの数の異なる 2 種以上の経路が存在することが明らかとなった。

上啹頭神経は喉頭粘膜の広い範囲の知覚を受容して いることが形態学的に明らかになっている。ヒトの上 
唉頭神経内枝をブロックした場合, 音声のピッチに細 かい動摇がみられるが平均的なピッチには変化がみら

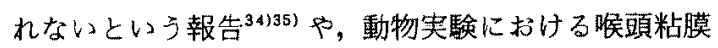
の知覚ブロック実験は, 音声のピッチに変化がみられ

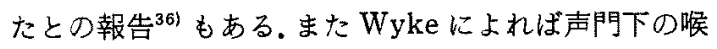
頭粘膜の局所麻酔により話声にはほとんど变化がみら れなかったが，ピッチの正確なコントロールとラウド ネスのコントロールを失っているため, 朗話には声の 乱れを生じたという ${ }^{43)}$.

以上より, 上喉頭神経内枝は喉頭粘膜の知覚受容器 からの求心性線維による触賞性フィードバックの一部 を構成し，全体的な音声のピッチを変化させない範囲 での細かいピッチコントロールに寄与している可能性 も否定できない.

また，一般にひとつの反射経路にシナプスの数の異 なる短いループと長いループが存在する場合, 長いル 一プは反射（運動）のより細かい, 精巧な調節を行っ ている可能性がある。

本研究の結果得られた late response と呼称した反 射応答は，声門閉鎖反射だけでなく，声帯のより精巧 な調節に寄与している可能性が示唆された。

一方, 反回神経刺激による誘発反応は，上喉頭神経 内枝刺激の場合と明らかに異なる潜時を示し，さらに 反復刺激に対して速やかな，かつ顕著な減衰を示した。 これは外界からの異物の下気道への侵入を防ぐという 目的とは合致しない特性であり，反回神経刺激の，こ の反射応答は下気道の保護のみを目的とした反射とは 考えにくい.

Andrew, BL の甲状喉頭蓋関節の関節受容器からの 求心性発射の記録を初めとし, 唉頭の粘膜, 関節包, 抒よび内啹頭筋には種々の知覚受容器の存在が報告さ れている371-42).

Wyke, BD は発声時には意識にの沽らない声带の stabilizing mechanism が作用し, 声带を pre-setされ た状態に維持するように働くと述べている。この stabilizing mechanism には subglottic mucosal mechanoreceptor, myotatic mechanoreceptor, articular mechanoreceptor をそれぞれ介する反射性 機構の存在を指摘している ${ }^{43) ~-46)}$.

また, Adzaku, FK, Wyke, BDによれば，ネコ喉 頭においてルフィ二小体様の構造が声帯下面に広く分 布し, 前方に多いと報告, さらにこの小体の機能につ いて呼吸ちよび発声時に求心性発射を介して喉頭筋の 活動に反射性制御を与えることを示唆している(7)48).
本研究で得られた甲状披裂筋誘発筋電図反応に対し て喉頭粘膜に加えた振動刺激が促通効果を示し, さら にその促通効果が振動刺激の周波数によりある程度依 存して応答した実験結果は, 喉頭粘膜で感受された振 動刺激が，反対側の内喉頭筋の筋活動に反射性に影響 を与えていることを示していると考えられた。

このような機構が, 高速振動する声帯または声門下 圧の変化を感受し, 反射的に声帯の長さ, 緊張をはじ めとする種々の声帯のパラメーターを变化させ, 最終 的には声帯の物性を制御している可能性も否定しえ ず, 今後, 喉頭における電気生理学的側面と声帯, 声 道の物性という側面を結ぶ研究が必要と考えられた。 また, 本研究では受容器一求心路一中枢一遠心路一効 果器 (笳)という反射経路を全体として観察しており, さらに各構成要素の特性を考虑した, 詳細な研究が必 要と考えられた。

\section{まとめ}

ウレタン,アルファクロラロース麻酔成猫の上诶頭 神経内枝および反回神経を電気刺激し，反対側の甲状 披裂筋筋電図を指標として誘発反応を検討，以下の結 果を得た。

1.上喉頭神経内枝の刺激により誘発された対側甲 状披裂筋筋電図には潜時の異なる 2 種類の反応波形が 認められた。

2. 上, 下丘間で脳幹切断後, 上喉頭神経内枝を刺 激すると，潜時の長い反応の消失が認められた。

3. 反回神経の刺激による誘発筋電図反応には，声 門下喉頭粘膜に加えた振動刺激による促通効果が認め られた。

4.この促通効果は, 喉頭粘膜の表面麻酔により， 速やかに抑制された。

5. 声門下喉頭粘膜に加えた振動刺激によるこの促 通効果は, 加えた振動刺激の振動周波数にある程度依 存した変化を示す場合が認められた。

\section{参考文献}

1）広瀬綮：㺍幁の機能.日気食会報 $38: 334-335$, 1987.

2) Sasaki CT : Physiology of the larynx in Otolaryn. gology Vol III, Harper \& Row, New York, 1977.

3) Martensson A : Reflex responses and recurrent discharges evoked by stimulation of laryngeal nerves. Acta Physiol Scand 57 : 248-269, 1963. 
4) Kirchner JA, Suzuki M: Laryngeal Reflexes and Voice Production. Ann NY Acad Sci 155: 98-109, 1968.

5) Suzuki M, Sasaki CT: Initiation of reflex glottic closure. Ann Otol Rhinol Laryngol 85: 382-386, 1976.

6) Suzuki M, Sasaki CT : Effect of various sensory stimuli on reflex laryngeal adduction. Ann Otol Rhinol Laryngol $86: 30-36,1977$.

7) Ogura JH, Lam RL : Anatomical and physiological correlations on stimulating the human superior laryngeal nerve. Laryngoscope 63: 947-959, 1953.

8）来間出征男：各種実験動物における喉頭反射について 一神経生理学的検索一。日気食会報 $24: 268-275$ ， 1973.

9) Borden GJ, Harris KS, 広瀬㢣訳：ことばの科学入 門. MRCメヂィカルリサーチセンター，東京，1984， pp 128-136.

10) Hirano M, Ohala J: Use of hooked-wire electrodes for electromyography of the intrinsic laryngeal muscles. J Speech Hearing Res 12 : 362-373, 1969.

11) Maruyama $\mathrm{N}$ et al: Unit response of the cat's auditory cortex to synthesized formants. Proc Japan Acad 55: 413-417, 1979.

12) Suzuki M, Kirchner JA: The posterior cricoarytenoid as an inspiratory muscle. Ann Otol Rhinol Laryngol 78: 849-865, 1969.

13) Doty RW, Bosma JF : An electromyographic analysis of reflex deglutition. J Neurophysiol 19:44-60, 1956.

14）村上泰：内喉頭筋反射上“ spastic-after discharge”に関する電気生理学的研究. 日耳鼻 79: 1420, 1976 .

15) Murakami $Y$, Kirchner JA: Reflex tensor mechanism of the larynx by external laryngeal muscles. Ann Otol Rhinol Laryngol 80: 46-60, 1971.

16) Murakami $Y$, Kirchner JA : Mechanical and physiological properties of reflex laryngeal closure. Ann Otol Rhinol Laryngol $81: 59-71,1972$.

17) 村上 泰: 喉頭収縮筋の生理 その 2 ; 下咽頭収縮筋 分類に関する検討 耳鼻臨床 $65: 1109-1117 ， 1972$.

18) Murakami $Y$, Kirchner JA: Electrophysiological properties of laryngeal reflex closure. Acta Otolaryng $71: 416-425,1971$.

19）村上 泰: 声門けいれんのメカニズムに関する電気生 理学的研究.日耳鼻 79:660-666，1976

20) Yamagiwa $M$ : Interaction of upper airway reflexes on protective laryngeal closure. Auris - Nasus . Larynx (Tokyo) 7:51-59, 1980.

21）山際幹和, 三吉康郎, 坂倉康夫, 福喜多啓三, 久保将彦

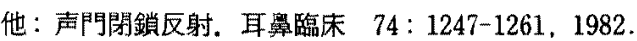

22) Car A, Jean A, Roman C: A pontine primary relay for ascending projections of the superior laryngeal nerve. Exp Brain Res $22: 197-210,1975$.

23）田中康政：ネコ喉頚ちよび咽䫒における感覚神経線稚 の走行ならびに分布.耳舅 32：1018-1044，1986.

24) Tanaka $Y, Y$ oshida $Y$, Hirano $M$ et al : Distribution of sensory nerve fibers in the larynx and pharynx An HRP study in cats, in Hirano M, Kirchner JA, Bless DM (ed) : Neurolaryngology, Recent advance, College-Hill Publication, Boston, 1987, pp 27-45.

25) Yoshida $Y$, Tanaka Y, Mitsumasu $T$ et al : Periph. eral course and intramucosal distribution of the laryngeal sensory nerve fibers of the cats. Brain Res Bull $17:$ 195-205, 1986.

26) Yoshida $Y$, Tanaka $Y$, Saito $T$ et al: The peripheral sensory innervation of the larynx in cats, in Fujimura O (ed) : Vocal Physiology : Voice Production, Mechanisms and Functions. Raven Press, New York, 1988, pp 93-113.

27) Hirose $H$ : Afferent impulses in the recurrent laryn geal nerve in the cat. Laryngoscope $71: 1196-1206$, 1961.

28) Bianconi R, Molinari G: Electroneurographic evidence of muscle spindles and other sensory endings in the intrinsic laryngeal muscles in the cat. Acta Otolaryng $55: 253-259,1962$.

29) 三浦 巧：ネコ喉頭知覚受容器に関する生理学的研 等。日耳舅 91: 1228-1236, 1988.

30) Miura $T$, Kaneko $T$, Suzuki $H$ et al : Frequency characteristics and distribution of mechanoreceptor in the larynx. in Fujimura $O$ (ed) : Vocal Physiology : Voice Production. Mechanisms and Functions. Raven Press, New York, 1988, pp 39-47.

31) Davis PJ, Nail BS : Quantitative analysis of laryngeal mechanosensitivity in the cat and rabbit. J Physiol 388: 467-485, 1987.

32) Davis PJ, Nail BS: The sensitivity of laryngeal epithelial receptors to static and dynamic forms of mechanical stimulation. in Fujimura $O$ (ed) : Vocal Physiology: Voice Production, Mechanisms and Functions. Raven Press, New York, 1988, pp 1-18.

33) Suzuki M, Kirchner JA : Sensory fibers in the recurrent laryngeal nerve. Ann Otol Rhinol Laryngol 
$78: 21-31,1969$.

34) Tanabe M, Kitajima K, Gould WJ: Laryngeal phonatory reflex. The effect of anesthetization of the internal branch of the superior laryngeal nerve. acoustic aspects. Ann Otol Rhinol Laryngol 84 : 206-212, 1975.

35) Gould WJ, Tanabe M : The effect of anesthesia of the internal branch of the superior laryngeal nerve upon phonation: An aerodynamic study. Folia phoniat 27 : 337-349, 1975.

36) Thoms $G$, Jürgens $U$ : Role of the internal laryngeal nerve in phonation: An experimental study in the squirrel monkey. Experimental Neurology 74:187 $-203,1981$.

37) Andrew BL: Proprioception at the joint of the epiglottis of the rat. J physiol 126:507 523, 1954.

38) Andrew BL: A functional analysis of the myelinat ed fibers of the superior laryngeal nerve of the rat. J physiol 133: 420-432, 1956.

39) Boushey HA, Richardson PS, Widdcombe JG: The response of laryngeal afferent fibers to mechanical and chemical stimuli. J physiol $240: 153-175,1974$.

40) Story AT: A functional analysis of sensory units innervating epiglottis and larynx. Experimental Neurology 20:366-383, 1968.

41) Sampson $S$, Eyzaguirre $C$ : Some functional characteristics of mechanoreceptors in the larynx of the cat. J Neurophysiol 27 : 464-480, 1964.

42) Eyzaguirre C, Sampson S, Taylor JR: The motor control of intrinsic laryngeal muscles in the cat. in Granit R (ed) : Muscular afferent and motor control. Almqvist \& Wiksell. Stockholm, 1966, pp 209 -225 .
43) Wyke BD : Reflexogenic contributions to vocal fold control systems. in Titze IR, Scherer RC (ed) : Vocal Fold Physiology. Biomechanics, Acoustics and Phonatory control. The Denver center for the performing Arts, Denver, 1983, pp 138-141.

44) Wyke BD: Laryngeal myotatic reflexes and phonation. Folia phoniat $26: 249-264,1974$.

45) Wyke $\mathrm{BD}$ : Laryngeal reflex mechanisms in phona. tion. XVIth Int. Congr. Logopedics and Phoniatrics. Interlaken, 1974, pp 528-537.

46) Wyke BD: Respiratory activity of laryngeal muscles: An experimental study. in Wyke BD (ed) : Ventilatory and Phonatory control Systems. Ox. ford University Press, London, 1974, pp 408-429.

47) Adzaku FK, Wyke BD: Innervation of the subglottic mucosa of the larynx and its significance. Folia phoniat $31: 271-283,1979$.

48) Adzaku FK: The morphological and functional characteristics of the innervation of the subglottic mucosa of the larynx. Ann Royal College Surgon Eng 62:426-431, 1980.

稿を終えるにあなり，御指導ならびに御校闃を賜りまし た恩師金子敏郎教授に㳭く感謝致します。

また, 実験の場を提供戴き, 終始御指導, 御助言戴きまし た千葉大学医学部第一生理学教室本間三郎名旁教授, 中島 祥夫教授に厚く御礼し上げます。

なお，本研究の要旨は第18回日本脳波・筋電図学会学術大 会，第90回日本耳鼻㸶㬋科学会総会において発表した。

(1989年12月 7 日受稿 1990年 2 月28日受理)

別刷請求先 $\bar{T} 280$ 干葉市亥鼻1-8-1 千葉大学医学部耳鼻咽喉科学教室 持田 晃 